\title{
Assessing the labor productivity of two methods of artificial pollination in oil palm crops from Colombia
}

\author{
Diego Alejandro Hernández Rendón ${ }^{1}$ (D), Edison Steve Daza ${ }^{2}$, Yeiner Arturo Acosta Hernández ${ }^{1}$ (B) \\ and Mauricio Mosquera-Montoya ${ }^{3, *}$ \\ ${ }^{1}$ Research Results Validation Unit, Colombian Oil Palm Research Center (Cenipalma), Villavicencio, Meta, Colombia \\ 2 Biology and Plant Breeding Research Program, Colombian Oil Palm Research Center (Cenipalma), Villavicencio, Meta, Colombia \\ ${ }^{3}$ Coordinator of the Research Results Validation Unit, Colombian Oil Palm Research Center (Cenipalma), Bogotá D.C., Colombia
}

Received 30 June 2021 - Accepted 7 February 2022

\begin{abstract}
Oil palm interspecific hybrids Elaeis oleifera $\times$ Elaeis guineensis $(\mathrm{O} \times \mathrm{G})$ are grown across approximately 68,000 hectares in Colombia. To address the limited natural pollination capacity of $\mathrm{O} \times \mathrm{G}$ hybrids and the difficulties associated with assisted pollination regarding the timing of E. guineensis pollen application, the Colombian Oil Palm Research Center (Cenipalma) conducted studies on induction of parthenocarpic fruits. Cenipalma confirmed that application of 1,200 ppm of 1-naphthaleneacetic acid (NAA) at different phenological stages enabled the formation of parthenocarpic fruits. This technological advance was termed artificial pollination. This paper presents the results from a research study aimed at assessing the labor productivity for two methods of NAA application (NAA in solid mixture and NAA in liquid suspension). From a methodological standpoint, a time and motion study was conducted to assess labor productivity for each NAA application method, with time data collected using the software Cybertracker on a mobile platform (smartphone). The results indicated that a worker can cover 3.9 hectares in a working day and sprinkle 303 inflorescences in a working day when applying NAA in solid mixture. On the other hand, when applying NAA in liquid suspension, the worker can cover 3.2 hectares and sprinkle 315 inflorescences (i.e. in a working day).
\end{abstract}

Keywords: artificial pollination / inflorescences / time and motion study / labor productivity

Résumé - Évaluation de la productivité du travail de deux méthodes de pollinisation artificielle dans les cultures de palmiers à huile de Colombie. Les hybrides interspécifiques de palmier à huile Elaeis oleifera $\times$ Elaeis guineensis $(\mathrm{O} \times \mathrm{G})$ sont cultivés sur environ 68000 hectares en Colombie. Pour faire face à la capacité limitée de pollinisation naturelle des hybrides $\mathrm{O} \times \mathrm{G}$ et aux difficultés associées à la pollinisation assistée concernant le moment de l'apport du pollen d'E. guineensis, le Centre colombien de recherche sur le palmier à huile (Cenipalma) a mené des études sur l'induction de fruits parthénocarpiques. Le Cenipalma a confirmé que l'apport de 1200 ppm d'acide 1-naphtalène-acétique (NAA) à différents stades phénologiques permettait la formation de fruits parthénocarpiques. Cette avancée technologique a été appelée pollinisation artificielle. Cet article présente les résultats d'une recherche visant à évaluer la productivité du travail de deux méthodes d'application du NAA (NAA en mélange solide et NAA en suspension liquide). D'un point de vue méthodologique, une étude de temps et de mouvement a été menée pour évaluer la productivité du travail pour chaque méthode d'application de NAA, avec des données de temps collectées à l'aide du logiciel Cybertracker sur une plateforme mobile (smartphone). Les résultats indiquent qu'un travailleur peut couvrir 3,9 hectares et saupoudrer 303 inflorescences en une journée de travail lors de l'application de NAA en mélange solide. Quant à l'application de NAA en suspension liquide, l'ouvrier peut couvrir 3,2 hectares et asperger 315 inflorescences en une journée de travail.

Mots clés : pollinisation artificielle / inflorescences / étude du temps et du mouvement / productivité du travail

\footnotetext{
*Corresponding author: mmosquera@cenipalma.org
} 


\section{Introduction}

The oil palm interspecific hybrids Elaeis Oleifera $\times$ Elaeis guineensis $(\mathrm{O} \times \mathrm{G})$ are currently among the fastest growing cultivars in terms of planted area in Colombia. Cultivation with $\mathrm{O} \times \mathrm{G}$ cultivars reached 68,000 ha in Colombia in 2018 (Romero et al., 2021). The main reason for the increased cultivation of $\mathrm{O} \times \mathrm{G}$ cultivars in Colombia is that some of these cultivars have some degree of resistance to bud rot (BR) (Navia et al., 2014; Ávila-Diazgranados et al., 2016), the most serious disease affecting oil palm crops in Latin America (Torres et al., 2016; Swinburne, 1993). The oil extracted from $\mathrm{O} \times \mathrm{G}$ has gained prominence in the production of goods for human consumption along the past decade because it has high concentrations of oleic acid, tocotrienols, and phytonutrients, which entail cardioprotective, antioxidant, and anti-inflammatory benefits (Mozzon et al., 2018; González-Diaz et al., 2021).

However, $\mathrm{O} \times \mathrm{G}$ cultivars, in general, have poor bunch formation caused by flowering asynchrony, poor natural pollination, and low pollen viability (Rincón et al., 2013), thereby requiring assisted pollination to ensure the formation of commercially usable bunches. Assisted pollination consists of applying pollen from Elaeis guineensis cultivars to female inflorescences in anthesis (phenological stage 607). Assisted pollination is crucial for bunch formation but requires regular intervention in the lots and is therefore costly. Specifically, the cost of assisted pollination in the Eastern oil palm growing region of Colombia accounts for approximately $20 \%$ of the yearly production costs of one hectare of crop and is only surpassed by fertilization, which accounts for $23 \%$ of the yearly production costs per hectare. The latter (i.e. yearly production costs per hectare) are around USD 1,700 per year (Mosquera et al., 2019).

As an alternative to assisted pollination and to obtain a higher number of parthenocarpic fruits, the Colombian Oil Palm Research Center (Cenipalma) conducted studies on the artificial induction of parthenocarpic fruits. According to Cenipalma's results, parthenocarpic fruits in $\mathrm{O} \times \mathrm{G}$ cultivars can contain up to $50 \%$ oil in the fresh mesocarp. The results of these studies indicated that application of 1-naphthaleneacetic acid (NAA), in liquid suspension at a concentration of $1200 \mathrm{ppm}$, at three different phenological stages (607: anthesis, 609: post-anthesis, and 703: 15 days after anthesis) enabled the formation of parthenocarpic fruits in the $\mathrm{O} \times \mathrm{G}$ hybrid, which increased the oil content of the bunches (Daza et al., 2020; Hernández et al., 2020). This novel technology, oriented towards the induction of parthenocarpic fruits, was termed artificial pollination. The increase in the oil extraction rate when using NAA has averaged four percentual points (meaning OER increased from $21 \%$ to $25 \%$ ). The later means that in one hectare of oil palm crops one may obtained an extra ton of crude palm oil by using NAA. At market current value, it means a gross benefit of USD 1,315/ha. However, the extra costs in which the grower incurs by applying NAA represented in additional labor and inputs may represent USD 172/ha. In consequence, the net effect on income of using NAA is estimated in USD 1,143/ha (Ruiz-Álvarez et al., 2021).

As mentioned before, the artificial pollination suggested by Cenipalma recommends application of NAA in liquid suspension (Romero et al., 2021). However, in oil palm plantations, owing to the difficulties in handling high volumes of water in the field, application of NAA in solid mixture was tested, and their results were in line with those of Cenipalma, this is, the oil content of oil palm fresh fruit bunches (FFB) increased.

In accordance to a toxicology study on the use of NAA over human health the US Environmental Protection Agency (EPA), the exposition to crops using NAA or food produced by means of using NAA are not harmful. Besides, the EPA concluded that if NAA is used within the allowed limits, it may not represent risk of contracting cancer to humans. Finally, the EPA study states that NAA is considered as a pesticide that may cause irritation on eyes, skin or mucous membranes if they are directly exposed to contact with NAA. Additionally direct exposition to NAA may cause coughing or running nose. In consequence, it is highly advised that workers performing artificial pollination should wear at all times personal protection items (PPI) (Environmental Protection Agency, 2012).

Assisted and artificial pollination are labor-intensive activities, with $80 \%$ to $90 \%$ of their costs corresponding to direct labor costs (Mosquera et al., 2019); therefore, information on how to invest in human resources more efficiently must be generated for decision-makers (Sanz et al., 2018). This article presents the results from a study aimed at determining the labor productivity of the two methods of artificial pollination (i.e., using either NAA in solid mixture or NAA in liquid suspension).

From a methodological standpoint, a time and motion study was conducted to determine the processes and performance of artificial pollination for both NAA application methods, as described above (Mosquera and García, 2005). When reviewing the literature, there were found only two former time and motion studies on pollination. The scarcity on literature evaluating artificial pollination in $\mathrm{O} \times \mathrm{G}$ palms is somehow expected considering the recent nature of this technology. Therefore, our study was performed to bridge this knowledge gap.

Regarding the previous studies revised, Fontanilla et al. (2016) evaluated the labor productivity of assisted pollination in $\mathrm{O} \times \mathrm{G}$ crops and found that a worker could pollinate on average 10 ha per working day and that their performance may vary depending upon environmental conditions (heat and humidity). A more recent work by Camperos et al. (2020) evaluated the artificial pollination with NAA in solid mixture at $\mathrm{O} \times \mathrm{G}$ crops from the Central oil palm growing region of Colombia, and found that a worker may artificially pollinate 1.99 ha and 163 inflorescences in a working day, when inflorescences are at $2.5 \mathrm{~m}$ of height. The difference in labor productivity reported by these studies is mainly explained by the fact that assisted pollination implies applying pollen of E. guineensis on each female inflorescence at anthesis (607), this is each inflorescence is treated once. On the other hand, the artificial pollination implies treating each inflorescence at three different stages $(607,609,703)$, in consequence the worker will have to treat more inflorescences in a working day. In synthesis, the work by Fontanilla et al. (2016) reports results for assisted pollination in which inflorescences are applied only once, then the labor yield is higher compared to ours. Meanwhile Camperos et al. (2020) report results on a similar regime of NAA applications but their results differ to ours 
Table 1. Characteristics of the lots in which this study was undertaken.

\begin{tabular}{lll}
\hline Lot number & 2 & $5 \mathrm{~A}$ \\
\hline Cultivar interspecific hybrid $\mathrm{O} \times \mathrm{G}$ & Coari $\times$ La Mé & Brazil $\times$ Djongo \\
Planting year & 2012 & 2012 \\
Planting density (palms/ha) & 115 & 115 \\
Average height of the inflorescences (m) & 2.15 & 2.31 \\
Lot area (ha) & 6.9 & 7.4 \\
\hline
\end{tabular}

Table 2. Processes flow chart symbology.

\begin{tabular}{ll}
\hline Process & Field's labors \\
\hline $\begin{array}{l}\text { Operation } \\
\text { Transportation }\end{array}$ & $\begin{array}{l}\text { An action is carried out. When it comes to artificial pollination of oil palms one may refer to applying NAA } \\
\text { Someone changes their location or moves something to a different position. When it comes to artificial } \\
\text { pollination of oil palms one may refer to the action of walking from one palm to the next } \\
\text { Inspection }\end{array}$ \\
$\begin{array}{l}\text { Verification of quality features or amounts required. For the case of artificial pollination, inspection is required to } \\
\text { find out inflorescences at phenological stages } 607,609,703 \text { that need to be treated } \\
\text { Time wasted (delay) }\end{array}$ & $\begin{array}{l}\text { Must be recorded when a circumstance occurs and it prevents the next process of being carried out. For instance, } \\
\text { in the artificial pollination process the equipment requires minor repairs }\end{array}$ \\
Storage & $\begin{array}{l}\text { Something is put into a safe place. An example would be to return tools and inputs to the plantation storage at } \\
\text { the end of the working day } \\
\text { The worker must decide. For instance, in the case of artificial pollination, the worker must decide whether it is } \\
\text { necision making }\end{array}$ \\
necessary to refill the backpack sprayer pump
\end{tabular}

because of the height at which inflorescences were treated. Camperos et al. (2020) treated oil palm trees with bunches at 2.8-3 m height, while we treated oil palm trees with bunches at 2.1-2.3 m height.

To the best of our knowledge, no studies on the labor productivity of artificial pollination have been carried out at the same location and have compared the two methods resulting from NAA in solid mixture and NAA in liquid suspension. Let alone the fact that this is the first time in which artificial pollination results are published for the Eastern oil palm growing region of Colombia.

In other words, the goal of this research was to compare the labor yield of performing artificial pollination by using NAA in solid mixture with respect to using NAA in liquid suspension under similar conditions of climate, soils, crop yield and plantation management. It was relevant because former literature refers to cases of study were one or the other presentation of NAA was implemented which made difficult to compare labor yields (according to NAA presentation). Finally, it was expected that labor yield was lower when workers applied NAA in liquid suspension because of the weight of the equipment which is greater to the one required for applying NAA in solid mixture.

\section{Methodology}

The study was conducted at the Palmar de las Corocoras Experimental Research Station (CEPC) located in the Eastern oil palm growing region of Colombia, more specifically in the municipality of Paratebueno (Cundinamarca). For this purpose, two lots grown with interspecific $\mathrm{O} \times \mathrm{G}$ hybrids were used (Tab. 1).

In these lots, artificial pollination with NAA was performed according to the protocol proposed by Cenipalma, which involves three applications of NAA to each inflorescence at the phenological stages of anthesis (stage 607), 7 days after anthesis (daa) (stage 609), and 15 dda (stage 703) at a dose of $240 \mathrm{mg}$ NAA $+2.76 \mathrm{~g}$ talc for the solid mixture and, $180 \mathrm{mg}$ $\mathrm{NAA}+150 \mathrm{~mL}$ water for the liquid suspension (Romero et al., 2021). The labor involved was assessed in operational terms.

\subsection{Characterization of the artificial pollination process}

The artificial pollination process was characterized by means of observation following the methodology by Sánchez et al. (2010) and Ruiz-Álvarez et al. (2020), which consists in identifying macroprocesses (repetitive work motions and/or activities). The performance of workers applying the NAA solid mixture was assessed for 12 working days, while the performance of workers using NAA in liquid suspension was assessed for 11 days.

To determine the operational dynamics, it was necessary to identify aspects such as the start and end times of the artificial pollination process, the paths followed by the workers in the field, and the tools used. Finally, the sequence of tasks and the places of the lot where the different activities of each task were conducted. The result of the characterization stage is a processes flow chart, depicted using the symbols proposed by the American Society of Mechanical Engineers (ASME) (Tab. 2). 


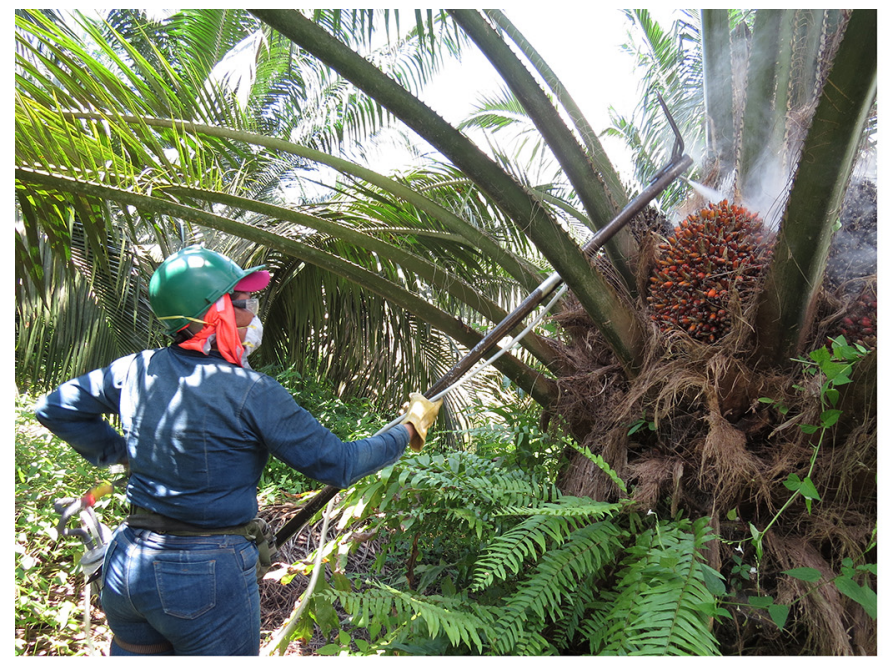

$1 \mathrm{~A}$

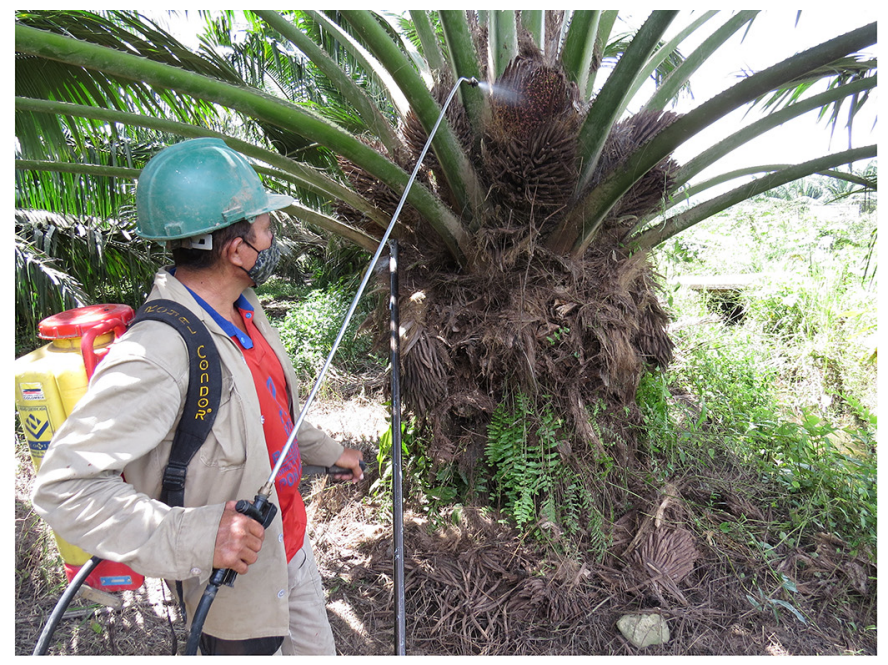

$1 B$

Fig. 1. Artificial pollination. (A) NAA in solid mixture. (B) NAA in liquid suspension.

Table 3. Tools used for artificial pollination.

\begin{tabular}{lll}
\hline & NAA solid mixture & NAA in liquid suspension \\
\hline \multirow{2}{*}{ Tool and empty weight } & Pneumatic pump: $593 \mathrm{~g}$ & Knapsack sprayer: $5.9 \mathrm{~kg}$ \\
Capacity & Spear (opening peduncular bracts - NAA spraying): $2.1 \mathrm{~kg}$ & $\begin{array}{l}\text { Spear (NAA spraying): } 600 \mathrm{~g} \\
\text { Metal hook (opening peduncular bracts): } 1.8 \mathrm{~kg}\end{array}$ \\
Spear length & $283 \mathrm{~g}$ & $20 \mathrm{~L}$ \\
& $2 \mathrm{~m}$ & NAA spraying: $1.5 \mathrm{~m}$ \\
& Injection system: pneumatic pressure & Opening peduncular bracts: $2 \mathrm{~m}$ \\
Description & Pressure required: $4.4 \mathrm{psi}$ & Injection system: hydraulic pressure \\
& Material: Aluminium, iron (spear), plastic (pneumatic pump) & Pressure required: $40 \mathrm{psi}$ \\
& & Nozzle: hollow cone $(40-120 \mathrm{psi})$ \\
& & Pressure regulator: $29 \mathrm{psi}$
\end{tabular}

At the CEPC, artificial pollination was performed weekly. That is, the workers visited the same lot once a week in search of inflorescences in anthesis (first application of NAA), or in stage 609 (second application of NAA), or in stage 703 (third application of NAA). Figure 1A shows a worker performing artificial pollination with NAA in solid mixture, and Figure 1B shows a worker performing artificial pollination with NAA in liquid suspension. The workers started their workday by collecting tools and supplies (Tab. 3).

Afterwards, each worker went to the lot assigned for carrying out artificial pollination. After arrival, they wear themselves with personal protective equipment to start working (helmet, mask and, goggles).

The worker walked from one palm to the next. The worker covered two oil palm rows at a time, since he zigzagged between palms and moved around each palm in order to search for inflorescences to treat (Fig. 2).

\subsection{Estimation of artificial pollination working time}

To record the time spent by the worker performing the processes of the artificial pollination, a different person gathered the data by means of using a mobile phone equipped with the software Cybertracker as suggested by Rincón et al. (2018). The mobile had already recorded a form with the tasks of the processes flow chart, which was obtained in the previous stage of the study. These forms were downloaded and run on a mobile platform (smartphone) with the Android operating system (Rincón et al., 2018). These forms allowed the person who was recording the time, to click on each process as it occurred and, instantly the time was recorded.

The working time should consider effective working time, work operations that are necessary but not directly related to its execution (receiving instructions, receiving equipment and supplies, getting to and from the workplace), work-supplements, and wasted time (unnecessary activities that affect the execution of work tasks). We elaborate further in the coming paragraphs.

Effective working time was the time that the worker exclusively dedicated to performing artificial pollination. The effective working time comprised the periods associated with work cycles. In this study a work cycle included the following operations:

- walk on the lots between palms;

- search for inflorescences to treat at each palm in the lot (607: first application of NAA, 609: second application of NAA, 703: third application of NAA); 


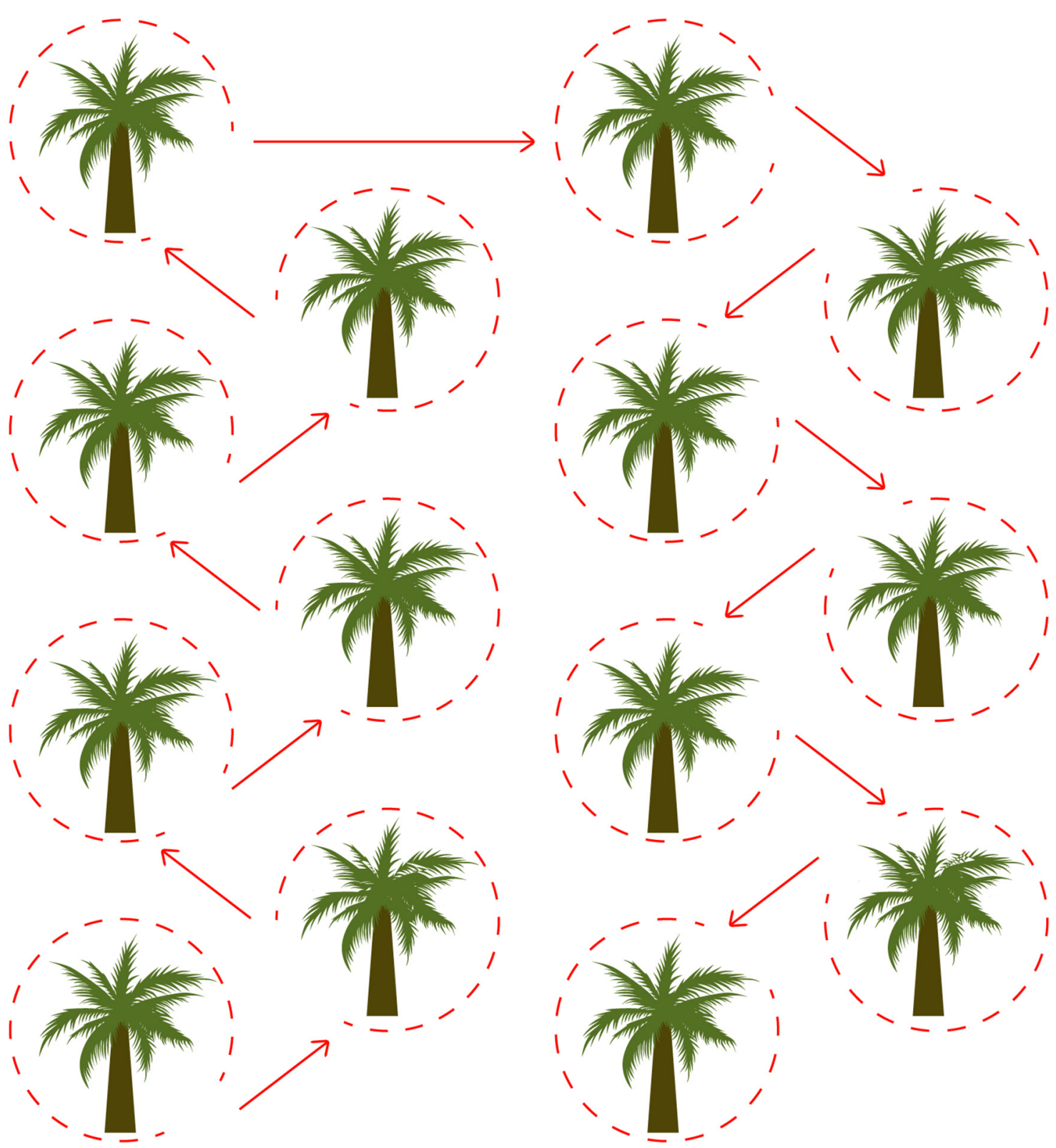

Fig. 2. Path followed by artificial pollination workers.

- opening of the peduncular bracts in inflorescences subjected to the first NAA application;

- NAA application;

- labelling the base of the leaf that carries the treated inflorescence (with the date and application - first, second, or third);

- recording the number of inflorescences treated with NAA.

At the plantation where this study was carried out, each worker is assigned an area for which he/she is responsible to keep it artificially pollinated along the year. It corresponds to 25 hectares and comprehend about three oil palm plots. This explains why it was not possible to assign more than one worker at the same area. In consequence we assigned two different workers with similar skills (by considering plantation records on inflorescences applied per day), working on oil palm plots of the same age (height of the bunches to be

treated), and with similar yield expressed in terms of tons of FFB per hectare (similar amount of bunches to treat).

In order to determine the sample size, there was an initial phase in which the two selected workers were followed during a week, along their working day, in order to establish the processes to be included at their processes flow chart. We also considered the time it takes to treat inflorescences on a palm (working cycle). At the end of this initial phase, we had data on 407 working cycles. It was estimated that on average a working cycle lasted 90.1 seconds with a standard deviation of 211.02 seconds. We used the sample size estimation by Martinez-Bencardino (2012), with a confidence level of 95\%, and an absolute error of 5.4 seconds. Based on these parameters we obtained a sample size of 5,133 working cycles, enough to capture the data variability, regarding time spent in each process. It must be noted that during a work cycle, the worker may find: zero, one, two, or three 
inflorescences requiring spraying with NAA. The number of inflorescences to treat affected the duration of the work cycle, so it was considered in the data analysis.

Work-supplements are a compensation in time that adds to the working time (Meyers, 2000). The compensation is due to the fatigue accumulated throughout the working day, cause by the weight of the tools and equipment used to perform the work, the environmental conditions under which the worker performs their work (heat and humidity), and personal time (hydration, meal, resting breaks and personal needs) (Camperos et al., 2020). It must be highlighted that there are standards for calculating the work-supplements that consider the factors and they are available for researchers developing time and motion studies (Meyers, 2000).

Lastly, wasted time refers to the time spent in activities that prevent the worker from executing their tasks (Niebel and Freivalds, 2004), such as interruptions by other workers, minor tool repairs, distractions, among others.

For the data gathering in each of the aforementioned plots (i.e. NAA solid mixture and NAA in liquid suspension), we considered every palm at the plot because the worker must make sure if there are inflorescences to treat with NAA (palm by palm). On each palm, we accounted for the necessary processes to complete the task of artificial pollination. For each process, we recorded the time elapsed. Summation of these processes (per palm) yields the time required to perform artificial pollination on a palm. In other words the observation unit is the palm. Finally, we compared the time required when using NAA in solid mixture with respect to the time required when using NAA in liquid suspension. For data analyses we used descriptive statistics considering the more adequate central tendency measures according to data frequency histograms. Note, since we had no chance to perform a strict experimental design due to the plantation logistics, we end up with observations at each plot that are not statistically independent from one another, which do not allow us to carry out valid statistical analyses since this is an assumption that should not be violated.

\subsection{Estimation of artificial pollination labor productivity}

Two indicators were considered to estimate the labor productivity:

- productivity in terms of area covered per working day (ha covered/working day): calculated as the summation of the area covered by the worker (according to the method used during the days of evaluation), divided into the number of days of evaluation (for each method);

- productivity in terms of inflorescences treated per working day (inflorescences treated/working day): calculated as the summation of inflorescences treated per day (according to the method used), divided into the number of working days evaluated (for each method).

\section{Results}

\subsection{Characterization of artificial pollination}

Regarding the processes in which workers performing artificial pollination, it was found that for both NAA presentations, the first process consists in walking from palm to palm. Once the worker arrives to a palm, he/she must check for female inflorescences at phenological stages 607, 609, and 703. Afterwards, the worker opened peduncular bracts of inflorescences subjected to first NAA application (stage 607). When using NAA in liquid suspension, the worker carried a backpack sprayer pump and a metal hook. When applying NAA in solid mixture, the worker used containers to carry NAA in solid mixture. The containers were connected to a pneumatic pump that pushed the NAA mixture along a hose adapted to a tool that has a bifurcation. One end enabled the worker to open peduncular bracts (metal hook) and the other end is a pneumatic sprayer to apply NAA.

Subsequently, when using NAA in either liquid suspension or solid mixture, the inflorescence got sprayed. Afterwards, the base of the leaf holding the inflorescence was labelled. In the same palm, the worker looked for structures previously sprayed with NAA, ensuring that each inflorescence was treated three times (at stages 607, 609, and 703). Lastly, the worker recorded the number of inflorescences sprayed for the first, second, or third time using a paper form and a pencil.

During the artificial pollination process, the workers should fill up their sprayers to continue their work. For this purpose, in the case of artificial pollination with NAA in solid mixture, the operator carried extra containers with him. In the case of artificial pollination with NAA in liquid suspension, when the workers ran out of NAA suspension, they walked to the designated place at the periphery of the lot and filled up the backpack sprayer with water and the mixture prepared the day before by their supervisor.

\subsubsection{Processes flow chart}

As a result of the field observations and as part of the evaluation process, a processes flow chart of artificial pollination was depicted (Tab. 4). There were similarities in the processes of applying NAA (liquid suspension and solid mixture). In other words, although the tools used were different, the process of setting up the work, moving around, spraying, collecting data, and completing the work was similar for both methods.

\subsection{Working time estimation}

Regarding NAA in solid mixture, it was found that in $6.9 \%$ of palms there were no inflorescences requiring treatment; in $70.85 \%$ of palms, one inflorescence required treatment; in $21.91 \%$ of palms, two inflorescences required treatment; and in the remaining $0.34 \%$ of palms, the worker treated three inflorescences. On the other hand, for the spraying of NAA in liquid suspension, it was found that; in $25.35 \%$ of palms, no inflorescence required treatment; in $70.95 \%$ of palms, there was one inflorescence to treat; in $3.40 \%$ of palms, two inflorescences required treatment; and in the remaining $0.60 \%$ of palms, the worker treated three female reproductive structures (i.e. inflorescences). The time data for each process was analyzed by means of frequency histograms, in order to choose the proper measure of central tendency (Tab. 5).

\subsubsection{Effective working time}

The effective working time spent in artificial pollination using NAA in solid mixture was $4.08 \mathrm{~h} /$ day (Tab. 6). The 
Table 4. Processes flow chart for artificial pollination (NAA in liquid suspension - NAA in solid mixture).

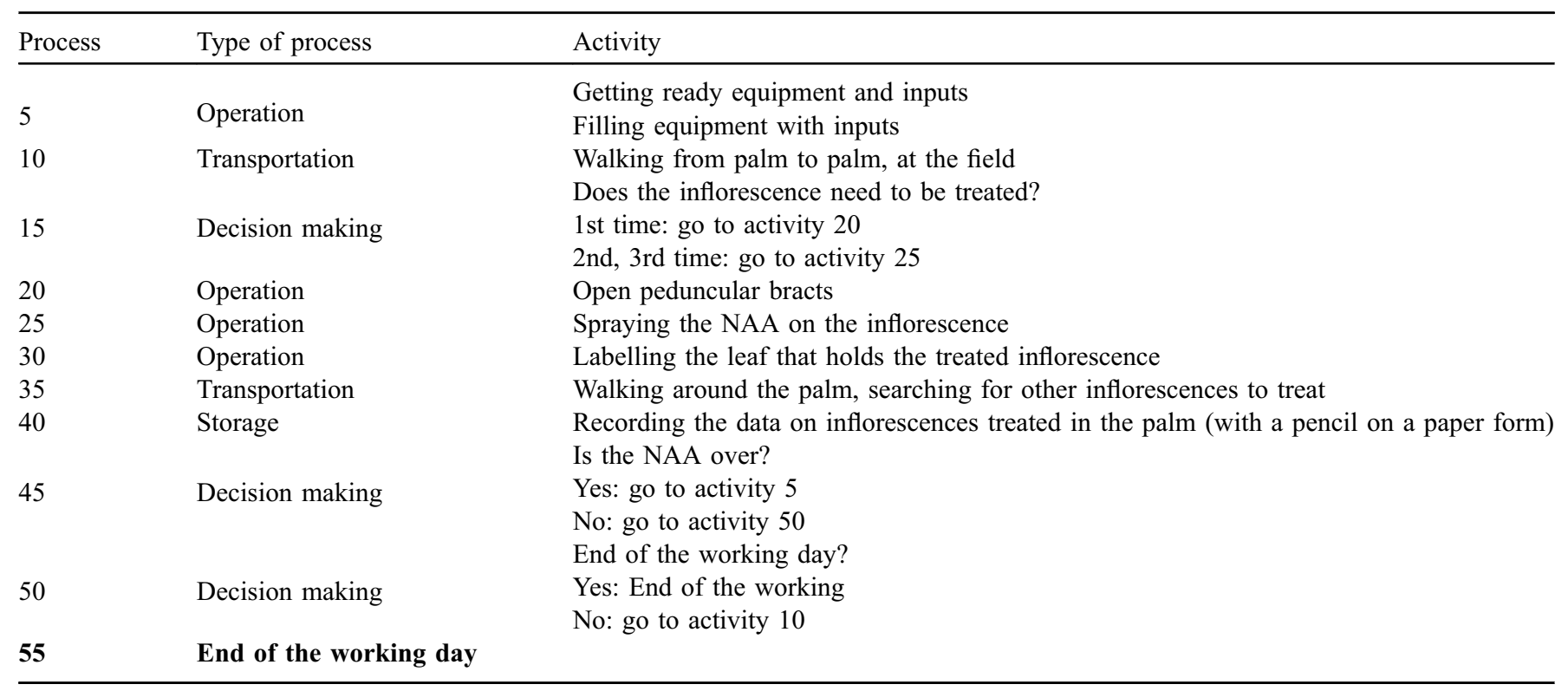

Table 5. Measures of central tendency according to process and NAA application method.

\begin{tabular}{llll}
\hline Method & Process & Measure of central tendency & Coefficient of variation \\
\hline & Walking from palm to palm & Median & 0.158 \\
& Search for inflorescences to be treated & Mean & 0.269 \\
& Open peduncular bracts & Mean & 0.264 \\
NAA in solid mixture & Spraying NAA on the inflorescence (1st time) & Median & 0.218 \\
& Spraying NAA on the inflorescence (2nd or 3rd time) & Mean & 0.153 \\
& Labelling the leaf that holds the treated inflorescence & Median & 0.609 \\
& Record inflorescences treated & Median & 0.437 \\
& Walking from palm to palm & Median & 0.511 \\
& Search for inflorescences to be treated & Median & 0.486 \\
& Open peduncular bracts & Mean & 0.357 \\
NAA in liquid suspension & Spraying NAA on the inflorescence (1st time) & 0.197 \\
& Spraying NAA on the inflorescence (2nd or 3rd time) & Mean & 0.184 \\
& Labelling the leaf that holds the treated inflorescence & Median & 0.74 \\
& Record inflorescences treated & Median & 0.692 \\
\hline
\end{tabular}

process that required the longest time was opening the peduncular bracts followed by walking from palm to palm, which accounted for $20.1 \%$ and $12.5 \%$ of the total effective time, respectively. The process that required the shortest time was labelling the base of the leaves, which accounted for $4.4 \%$ of the effective working time. In this case, work-supplements accounted for $11.3 \%$ of the effective working time (that is, $4.08 \mathrm{~h})$.

In artificial pollination with NAA in liquid suspension, the effective working time was 5.46 hours (Tab. 6). Similar to NAA application in solid mixture, opening the peduncular bracts was the process that required the most time, accounting for $19.2 \%$ of the total effective working time. The activities that required shorter times were recording data and observing the state of maturity of the inflorescence, accounting for $0.73 \%$ and $0.54 \%$ of the total effective time, respectively. In this case, work-supplements accounted for $16.4 \%$ of the effective working time. In conclusion, workers performing artificial pollination with NAA in liquid suspension are to be rewarded with greater time supplements due to the fact that they are carrying a knapsack sprayer of greater weight than the neumatic pump, and they need to fill it repeatedly which implies moving to specific filling points at the plot.

Time spent in work operations necessary but not directly related to artificial pollination accounted on average for 1.7 hours $(102 \mathrm{~min})$ in the case of NAA in solid mixture, and 1.43 hours $(85.8 \mathrm{~min})$ in the case of NAA in liquid suspension. This time is measured from the moment the worker arrives to the plantation, reports their arrival to supervisor, is provided with instructions for the day, picks up equipment and inputs 
Table 6. Effective working time. Processes and share on total effective time, according to ANA spraying method.

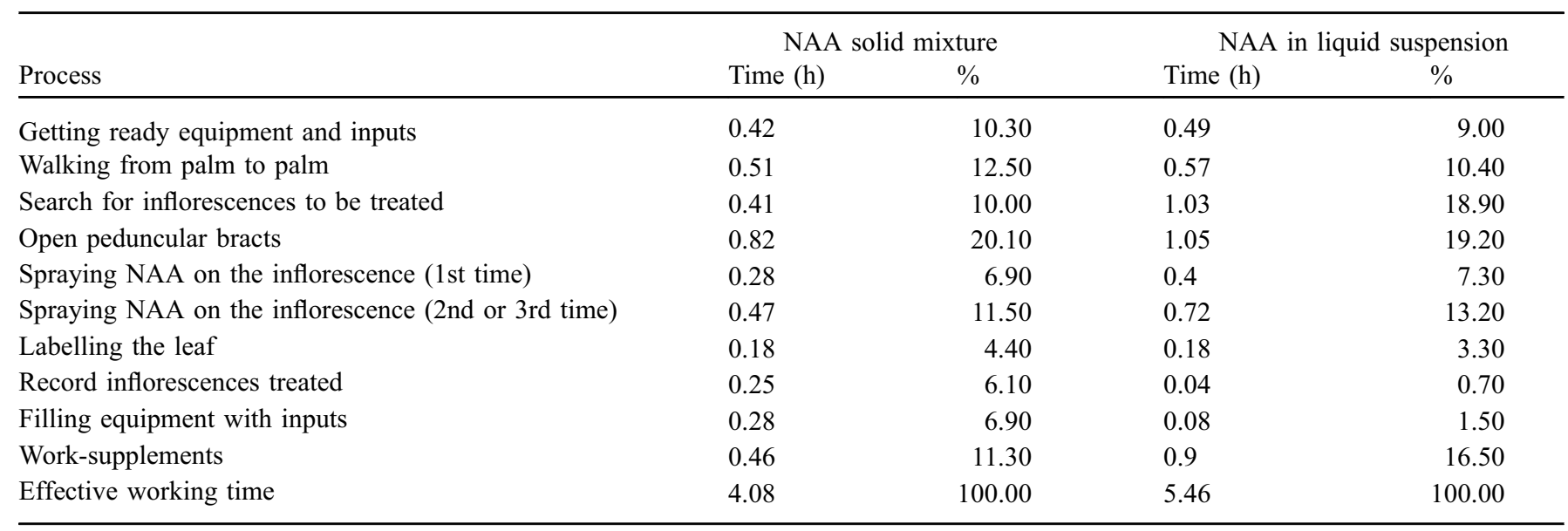

and, gets to the field. In the afternoon, the worker must come back from the field in order to return the equipment and, to turn in their daily report. The time is less in the case on NAA in liquid suspension compared to NAA in solid mixture, because in the mornings, the worker is transported to the field due to the weight he carries (i.e. ANA liquid suspension).

\subsubsection{Wasted time}

It accounted for 1.2 hours $(72 \mathrm{~min})$ for the method using NAA in solid mixture and accounted for 1.1 hours $(66 \mathrm{~min})$ when using NAA in liquid suspension. It must be highlighted that the main cause of wasting time corresponds to breakdowns and obstructions of the NAA spraying equipment, which prevented work until simple repairs were made by the worker at the field. The latter is followed by lot conditions that made it difficult to move around the lot (such as irrigation and drainage channels). The third cause consists in interruptions by other workers or phone calls. Finally, it was found that heavy rainfall prevents the workers from accomplishing their task since NAA may get washed away.

Considering the causes of wasted time provides ideas for improving the working conditions. From this analysis one may infer that developing efficient tools for spraying NAA is a must in which companies and researchers should be working. Additionally, managerial staff from the plantation, took note on the need of building bridges to facilitate the job of field workers.

\subsection{Labor productivity}

On average, a worker applying NAA in solid mixture visited 449 palms per working day (equivalent to 3.9 ha) and treated 303 inflorescences per working day. Conversely, when applying NAA in liquid suspension, the worker visited 368 palms per workday ( 3.2 ha) and treated 315 inflorescences per workday. This result indicates that, the worker covered $17.8 \%$ more area when applying NAA in solid mixture compared to applying NAA in liquid suspension. It was evident that the physical effort demanded of the worker when applying NAA in the liquid suspension was greater than that required to apply NAA in a solid mixture and it effects the labor productivity expressed in terms of area covered. Consequently, in order to comply with a goal of more than 300 inflorescences treated per day, the worker increased their effective working time by $1.38 \mathrm{~h}$.

Note the worker treated $4 \%$ fewer inflorescences when applying the solid mixture than when applying the liquid suspension, this is related to the number of inflorescences requiring treatment and not with the NAA presentation that was used for artificial pollination.

\subsection{Sensitivity analysis: comparison of labor productivity considering homogeneous yield of the plots}

We gathered information from two different lots that had different amounts of inflorescences to treat, which introduces some noise in the comparison of NAA presentations. In consequence, we present an analysis in which we simulate that both plots have the same yield (i.e. same amount of inflorescences to treat). As mentioned before, the worker may find oil palm trees with zero to three inflorescences to treat. The latter must be considered because the larger the number of inflorescences in a palm requiring NAA application, the longer it will take to the worker to advance to the next palm (Tab. 7).

The results of comparing the two NAA presentation in a hypothetic scenario of having the same number of inflorescences in the field (homogeneous yield) indicate that one may cover 2.5 ha per working day when applying NAA in liquid suspension, while one may cover 3.6 ha per working day when applying NAA in solid mixture (difference is of $32 \%$ in terms of labor productivity in favor of NAA in solid mixture) (Tab. 7). This results in a cost per inflorescence of USD 0.05 with NAA in solid mixture compared to USD 0.07 using NAA in liquid suspension.

However, previous results by García et al. (2020) indicated that one may obtain a greater average bunch weight when using NAA in liquid suspension ( $2 \mathrm{~kg}$ out of $14 \mathrm{~kg}$ ). If this is the case one should not rule out the possibility of using the latter (i.e. NAA in liquid suspension) since it may help increasing crop yield. At the end the decision should consider FFB selling 
Table 7. Comparison of labor productivity considering homogeneous yield.

\begin{tabular}{|c|c|c|c|c|c|}
\hline \multirow{2}{*}{$\begin{array}{l}\text { Number of inflorescences } \\
\text { to treat }\end{array}$} & \multirow[t]{2}{*}{ Palms/ha } & \multicolumn{2}{|c|}{ NAA solid mixture } & \multicolumn{2}{|c|}{ NAA liquid suspension } \\
\hline & & $\begin{array}{l}\text { Time elapsed } \\
\text { per working cycle (s) }\end{array}$ & Total time (s/ha) & $\begin{array}{l}\text { Time elapsed per } \\
\text { working cycle (s) }\end{array}$ & Total time $(\mathrm{s} / \mathrm{ha})$ \\
\hline 0 & 23 & 12.4 & 285.0 & 17.7 & 406.9 \\
\hline 1 & 64 & 35.7 & 2286.5 & 69.0 & 4416.5 \\
\hline 2 & 25 & 100.4 & 2509.7 & 110.4 & 2759.3 \\
\hline Total & 115 & & 5388.3 & & 7930.7 \\
\hline
\end{tabular}

prices. If the gain in weight offsets the increase in the labor costs it should be preferred to use NAA in liquid suspension.

\section{Conclusions}

It was achieved the objective of comparing the processes involved in artificial pollination and the labor productivity of the methods resulting from using NAA in two different presentations. This study showed that NAA presentation (either solid mixture or liquid suspension) impacted the labor productivity of artificial pollination. This information is of extreme relevance for managers of $\mathrm{O} \times \mathrm{G}$ crops, given the weight of artificial pollination in production costs.

The evaluation of the artificial pollination processes of the two NAA application methods (NAA in the liquid suspension and in a solid mixture) indicated that the process requiring the longest time was opening the peduncular bracts, which is why research efforts should be made to shorten this time or eliminate the need to remove the bracts in order to increase the number of palms visited per day (and thus increase the number of inflorescences pollinated per day). Additionally, it was found that an important portion of the artificial pollination working day is dedicated to minor repairs of the application equipment, so that is another opportunity for researchers and agricultural equipment companies to ease the artificial pollination by providing solutions for equipment performance.

The results of this study suggest that the number of flowers to be treated (in other words, crop yields) may affect worker productivity in terms of area treated. Accordingly, when the crop has high yields (expressed in metric tonnes of fresh fruit bunches per hectare $-\mathrm{t} \mathrm{FFB} \mathrm{ha}^{-1}$ ), the pollination worker will find more inflorescences per palm and more palms with inflorescences compare to a low-yield crop. Consequently, the daily goals should not be expressed in terms of area covered but in terms of number of flowers pollinated per day.

The latter is to be considered for crops with marked seasonality as well. That is, the worker will find a higher number of inflorescences to be treated at some periods of the year. Thus, managers must be flexible in terms of daily goals along the year. Therefore, goals must be set in terms of the number of inflorescences to be treated.

Lastly, the process of spraying NAA in liquid suspension involved handling water in the plantation lots, which is often unwelcomed by palm crop managers, especially if NAA in solid mixture clearly makes it possible to cover a greater area in a workday. However, the use of NAA in the liquid suspension should not be ruled out based on these results. Before deciding which NAA method should be used (either NAA in solid mixture or NAA in liquid suspension), managers must consider whether the method affects variables such as average bunch weight, fruit set and oil content. In the case, one decides for using NAA in liquid suspension it will be necessary to compensate the worker for the extra effort imputed or, decreasing the number of inflorescences demanded per working day.

Acknowledgments. The authors express their gratitude to the Fondo de Fomento Palmero (FFP) for providing the financial resources needed to conduct this study. We also thank the managerial staff of the CEPC, and specially Nubia Rairán, for their collaboration in undertaking this study. We are also grateful to Estefanía Vargas (Statistics) and Jhonatan Camperos (crop researcher) for their helpful comments that improved our work.

\section{References}

Ávila-Diazgranados R, Daza E, Navia E, Romero H. 2016. Response of various oil palm materials (Elaeis guineensis and Elaeis oleifera $\times$ Elaeis guineensis interspecific hybrids) to bud rot disease in the southwestern oil palm-growing area of Colombia. Agronomía Colombiana 34: 74-81. https://doi.org/10.15446/ agron.colomb.v34n1.53760.

Camperos JE, Pulido N, Munévar DE, et al. 2020. Estudio de tiempos y movimientos para la polinización artificial: Estudio de caso en una plantación de Santander (Colombia). Palmas 41(3): 11-23.

Daza E, Ayala-Díaz I, Ruiz-Romero R, Romero HM. 2020. Effect of the application of plant hormones on the formation of parthenocarpic fruits and oil production in oil palm interspecific hybrids (Elaeis oleifera Cortes $\times$ Elaeis guineensis Jacq.). Plant Production Science: 1-9. https://doi.org/10.1080/ 1343943X.2020.1862681.

Environmental Protection Agency. 2012. 1-naphthaleneacetic acid; pesticide tolerances. Federal Register/Vol. 77, No. 89/Tuesday, May 8, 2012/Rules and Regulations.

Fontanilla C, Rincón V, Mesa E, Mariño D, Barrera E, Mosquera M. 2016. Estimación del rendimiento de la mano de obra en labores de cultivo de palma de aceite: caso polinización asistida. Palmas 37(2): 21-35.

García A, Ibagué D, Munévar DE, Hernández JS, Mosquera Montoya M. 2020. Polinización artificial: ¿ANA en suspensión líquida o ANA en mezcla sólida? Palmas 41(4): 15-26. 
González-Diaz A, Pataquiva-Mateus A, Garcia-Nunez JA. 2021. Recovery of palm phytonutrients as a potential market for the byproducts generated by palm oil mills and refineries - A review. Food Bioscience 41(5): 100916. https://doi.org/10.1016/j. fbio.2021.100916.

Hernández D, Rodríguez J, Daza E, Lemus L, Mosquera M. 2020. Punto óptimo de cosecha de racimos para híbridos interespecíficos $\mathrm{O} \times \mathrm{G}($ Coari $\times$ La Mé) asperjados con reguladores de crecimiento. Boletín El Palmicultor (580): 16-17.

Martinez-Bencardino C. 2012. Estadística y muestreo (Décimo tercera ed.). Bogotá: Ecoe Ediciones.

Meyers F. 2000. Estudio de tiempos y movimientos para la manufactura ágil. Edita Alfa Omega. Segunda edición. México: Ciudad de México.

Mosquera M, García A. 2005. Estudios de tiempos y movimientos para la agroindustria colombiana de la palma de aceite. Centro de Investigación en Palma de Aceite, Cenipalma (Colombia). Ceniavances (129): 1-4.

Mosquera M, López D, Ruiz E, Valderrama M, Castro L. 2019. Mano de obra en cultivos de palma aceitera de Colombia: participación en el costo de producción y demanda. Palmas 40(1): 46-53.

Mozzon M, Foligni R, Tylewicz U. 2018. Chemical characteristics and nutritional properties of hybrid palm oils. Palm Oil 149: 149170. https://doi.org/10.5772/intechopen.75421.

Navia EA, Ávila RA, Daza EE, Restrepo EF, Romero HM. 2014. Assessment of tolerance to bud rot in oil palm under field conditions. Eur J Plant Pathol 140: 711-720. https://doi.org/ 10.1007/s10658-014-0491-9.

Niebel B, Freivalds A. 2004. Ingeniería industrial, métodos, estándares y diseño del trabajo. (Undécima edición ed.). Bogotá: Prentice Hall.

Rincón V, Molina A, Torres JL. 2018. Elaboración de formularios móviles digitales para el registro de datos en plantaciones de palma de aceite (Principios básicos). Bogotá: Cenipalma.
Rincón SM, Hormaza PA, Moreno LP, et al. 2013. Use of phenological stages of the fruits and physicochemical characteristics of the oil to determine the optimal harvest time of oil palm interspecific $\mathrm{O} \times \mathrm{G}$ hybrid fruits. Industrial Crops and Products 49: 204-210. https://doi.org/10.1016/j.indcrop.2013.04.035.

Romero HM, Daza E, Ayala-Díaz I, Ruiz-Romero R. 2021. High-oleic palm oil (HOPO) production from parthenocarpic fruits in oil palm interspecific hybrids using naphthalene acetic acid. Agronomy 11 (2): 290. https://doi.org/10.3390/agronomy11020290.

Ruiz-Álvarez E, Banguera J, Pérez Toro W, Hernández Hernández J, Arévalo J, Mosquera Montoya M. 2020. Technical and economic assessment of two harvesting tools for young Elaeis oleifera $\times E$. guineensis oil palms. Agronomía Colombiana 38(3): 418-428.

Ruiz-ÁlvarezE, Daza ES, Caballero-Blanco K, Mosquera-Montoya M. 2021. Complementing assisted pollination with artificial pollination in oil palm crops planted with interspecific hybrids $\mathrm{O} \times \mathrm{G}$ (Elaeis guineensis $\times$ Elaeis oleifera): is it profitable? OCL 28: 27.

Sánchez C, Fontanilla C, Mosquera M. 2010. Métodos para el desarrollo de estudios de tiempos y movimientos para labores del cultivo en palma de aceite. Bogotá (Colombia): Tecnologías para la agroindustria de la palma de aceite: Guía para facilitadores, $78 \mathrm{p}$.

Sanz JI, Mosquera M, Beltrán JA, Palm CO. 2018. Closing yield gaps for small-and medium-scale oil palm producers: improving cultivation practices Research Center-Cenipalma, Colombia. In: Achieving sustainable cultivation of oil palm, volume 2. Burleigh Dodds Science Publishing, pp. 403-426.

Swinburne TR. 1993. Fatal yellows bud rot and spear rot of African oil palm. A comparison of the symptoms of these diseases in Brazil, Ecuador and Columbia. Planter 69(802): 15-23.

Torres GA, Sarria GA, Martinez G, Varon F, Drenth A, Guest DI. 2016. Bud rot caused by Phytophthora palmivora: a destructive emerging disease of oil palm. Phytopathology 106: 320-329. https://doi.org/10.1094/PHYTO-09-15-0243-RVW.

Cite this article as: Hernández Rendón DA, Daza ES, Acosta Hernández YA, Mosquera-Montoya M. 2022. Assessing the labor productivity of two methods of artificial pollination in oil palm crops from Colombia. OCL 29: 12. 